\title{
Internal Capital Markets in Russian Business Groups: Evidence from Corporate Investments
}

\section{Yana Korotkova}

PhD student, Department of Finance and Credit, Faculty of Economics

$\underline{\text { ORCID }}$

E-mail: yikorotkova@econ.msu.ru

Lomonosov Moscow State University, Moscow, Russia

Journal of Corporate Finance Research, Vol. 14, No. 2, pp. 58-71 (2020)

DOI: https://doi.org/10.17323/j.jcfr.2073-0438.14.2.2020.58-71

Received 13 April 2020 | Peer-reviewed 15 May 2020 | Accepted 25 May 2020 


\section{Internal Capital Markets in Russian Business Groups: Evidence from Corporate Investments}

\section{Abstract}

The purpose of this paper is to assess the impact of the internal capital markets on the investments of Russian groupaffiliated companies mediated by the degree of the firms' financial constraints.

Our research is prompted in line with the question of motivation for the use of internal capital markets, and whether the reallocation of intragroup funds help mitigate financing constraints of group members and facilitate their investments. We apply the generalised method of moments (GMM) to estimate investments models based on data for 514 Russian companies affiliated with 48 business groups over the period from 2014 to 2018. Following the existing studies based on the Euler equation model, we analyse the relationship between subsidiaries' investments and such factors as lagged investments, sales, leverage, asset profitability and liquidity as well as the size of both subsidiaries and their groups. The results indicate that leverage and profitability of business groups positively influence the investment activity of subsidiaries. These findings support our hypotheses that the internal capital markets of Russian business groups are active and help mitigate the financial constraints of affiliated companies. Subsidiaries' investment activity is negatively related to their asset profitability which is typical for propping practices followed by controlling shareholders. The results also show some evidence of the positive relationship between subsidiaries' cash flows and investments, demonstrating that the internal capital markets in Russia do not eliminate the financial constraints of group-affiliated companies.

The novelty of this work is our demonstration how the internal capital markets of business groups operate and influence corporate activities, which has not been sufficiently shown in prior research. Our findings may be useful for managers seeking for mechanisms to increase the financial resource availability for large and medium companies in the context of sanctions, macroeconomic instability and the less-developed financial markets in Russia.

Key words: internal capital market, business group, financing constraints, investments, tunneling, propping JEL classification: G31, G32, O16 


\section{Introduction}

Wide access to capital markets is a prerequisite for comprehensive development and stable functioning of any company. In recent years, the uncertainty of economic policy in Russia and the insufficient depth of the country's financial system have adversely affected the availability of external finance for domestic enterprises. Anti-Russian sanctions and the continued risks of new restrictive measures have forced Russian companies to adapt to the limited funding available from foreign investors. Due to the combination of these factors, the amount of capital available to domestic enterprises is often insufficient to satisfy their financial needs, making it vital to search for tools that can mitigate financial constraints. It implies not only the key role of retained earnings and other internal funds of individual companies, but also the growing significance of internal capital markets of business groups that allow their participants to attract temporarily free resources from affiliated companies to finance their activities.

Business groups have gained prominence in many countries, both developing and developed. Corporate groups also occupy strong positions within the Russian economy. As of the end of 2019, all public companies whose shares are included in the Moscow Exchange quotation lists 1 and 2 are group affiliated. In the view of the Gaidar Institute, the search for an institutional model for the economic growth consolidation in Russia was periodically focused either on private business facilitation or state expansion in the economy, while financial-industrial groups have been consistently exerting a predominant impact on the economic development of the country [40, p. 30].

When the availability of external financing is limited, the access of group-affiliated companies to internal capital market resources becomes a source of strategic advantage. Both the volumes and efficiency of their investments may depend on the in-depth understanding of the internal capital market operation. Though recent studies by V. Cherkasova and $\mathrm{O}$. Teplova have examined the impact of financing constraints on investments of Russian companies based on the investment-cash flow sensitivity analysis $[13 ; 14]$, they did not consider any differences between group-affiliated and stand-alone companies. Therefore, the role of internal capital markets in easing financing constraints to facilitate corporate investment in Russia still requires examination. Thus, the aim of this study is to assess the impact of internal capital markets of Russian business groups on the investment activity of participating companies at the current stage of economic development in Russia.

Our research results contribute to a more detailed understanding of the internal capital market as a potential mechanism for the pooling of intragroup funds by financially constrained firms to accept profitable investment opportunities, especially in the context of the ongoing anti-Russian sanctions, general macroeconomic instability, and inert development of financial markets.

Prior research provides ambiguous evidence as to the impact that internal capital markets pose on the investment efficiency of foreign business groups. Studies by T. Hoshi and co-authors, R. Lensink and co-authors, and M. Deloof showed that internal capital markets relax financial constraints of group-affiliated firms by substituting for external capital markets $[29 ; 16]$ and enhancing access to external funds [36]. Results reported by $\mathrm{H}$. Almeida and co-authors [2] and A. Ang and co-authors [3] demonstrated that internal capital markets facilitate profitable investment under adverse funding shocks faced by group-affiliated companies. J. Mota and M. dos Santos argue that internal capital markets of modern business groups in the euro area stimulate investments of subsidiaries with higher growth opportunities [37]. Alternatively, after an analysis of investment in Russian financial-industrial groups, E. Perotti and S. Gelfer concluded that the extent of intragroup funds redistribution might allow private benefits extraction by controlling shareholders [39]. Research by A. Gautier and M. Hamadi revealed that active internal capital markets may cause low performing subsidiaries to rely more on group financing, hence encumbering investment efficiency of business groups [23].

In Russia, integration processes and business groups were often the focus of academic research in the 2000s owing to the studies by S. Avdasheva, V. Dementiev, T. Dolgopyatova, and V. Golikova [4; 17], but despite their continuing economic significance, these topics gradually lost the attention of researchers. Russian studies on internal capital markets of that period, carried by D. Brodskiy and A. Kulemin investigated the links between investment strategies of domestic business groups and internal capital markets [9] and the impact of internal capital markets on value creation in business groups [33]. More than a decade ago A.Shumilov and N.Volchkova examined the efficiency of internal capital markets in Russia with the use of the cash flow sensitivity of cash approach [43], revealing that internal capital markets failed to boost liquidity of group-affiliated companies at the turn of the $20^{\text {th }}$ and $21^{\text {st }}$ centuries. Whether the effects of internal capital markets have changed since then is still an open research question that motivated this study.

The remainder of this paper is organised as follows. The literature review develops a general perspective on the motives for the use of internal capital markets and the impact that their functioning may impose on the financial constraints and investments of group-affiliated companies. The next two sections specify the hypotheses and the investment model used in the empirical part of the study. The section on the empirical research begins with an explanation of the sample construction, then provides descriptive statistics about the firms and variables analysed and presents the results of our estimations. The final section summarises the main findings.

\section{State of knowledge}

The notion of an internal capital market refers to the allocation of capital resources between different business units (in a multidivisional company) or subsidiaries (in 
a business group) [8, p. 39], or financial linkages among group companies [25, p. 760]. From the turn of the $20^{\text {th }}$ $21^{\text {st }}$ centuries there is an ongoing debate on whether internal capital markets of business groups create value for group members [31] or, on the contrary, undermine it due to opportunistic actions taken by controlling shareholders [28]. The nature of the internal capital market impact on the value of group-affiliated companies is largely determined by the motives behind its usage provided by the controlling owner of the group. The literature identifies three broad (not necessarily mutually exclusive) motives for the redistribution of financial resources within group-affiliated companies: (1) to tunnel funds out of firms at the expense of minority shareholders; (2) to support group members that are subject to financial distress; (3) to fund more profitable investment projects within the business group [25, p. 766]. These motives correspond with theoretical hypotheses about the nature of reallocation of funds on an internal capital market, which are: (1) tunneling, (2) propping, and (3) financing advantage (mitigation of financing constraints) hypotheses.

Group companies can be differentiated by the size of their financing deficits (surpluses) and by the cash-flow rights of the controlling shareholder, indicating the fraction of dividends the shareholder receives. Significant differences in the cash-flow rights among companies within a business group create strong motives for tunneling, i.e. extraction of private benefits by the controlling shareholder and expropriation of the minority ones [19]. Propping aims at saving a financially distressed company for the sake of future profit sharing and/or stealing [22, p. 744]. The research on tunneling and propping shows that these practices regularly co-exist in business groups as controlling shareholders are prone to tunnel funds from financially solid companies and inject resources into financially weaker ones [38]. The financing advantage hypothesis implies that a controlling shareholder reallocates intragroup funds towards financially constrained companies. In this case, the direction of financial flows within an internal capital market is determined not by the differences in the controlling shareholder's cash-flow rights among companies, but by the differences in internal funds availability among the companies.

A group of researchers have examined the motives for the active usage of internal capital markets based on the data on intragroup lending, by investigating the origin and settlement of such loans. The findings of G. Jiang and colleagues shed light on widespread tunneling practices through intragroup loans in Chinese listed companies [27], as the balances of other receivable (incorporating intragroup loans) scaled by total assets proved to be larger for small, less profitable and more leveraged companies, i.e. those companies where the benefits of tunneling should outweigh its costs. By investigating the internal debt concentration of Belgian private business group affiliates, N. Dewaelheyns and C. Van Hulle demonstrated that subsidiaries with limited access to external financing are on average characterised with the highest use of inter- nal debt in line with the financial advantage hypothesis [18]. D. Buchuk and co-authors studied internal capital markets of Chilean business groups by analysing the lending relationships between group-affiliated companies and showed that intra-group lending in Chile is more consistent with the financing advantage hypothesis and significantly less with tunneling [10]. Recent analysis of intra-group loan payable and receivable balances of Russian public companies provided evidence that the controlling shareholders of Russian business groups combine both financing advantage and tunneling strategies while making decisions on the financing of their business [32]. In this study, we apply an even more widely-used framework to investigate the mechanism of internal capital market functioning that is based on the analysis of its effects on the financing constraints of group affiliated companies.

In a world without market imperfections, company investment decisions would be determined by investment opportunities (often measured by Tobin's Q) and the demand for the company's products. Introduction of capital market frictions into investment research in the 1980s showed that a firm's investment can be limited by the financial resources it generates, as capital market imperfections lead to external funds being more expensive than company's internal resources [20]. If the gap in the cost of internal and external finance is small, fluctuations in the volume of internal funds available can be relatively easily smoothed out by raising additional external finance. However, when such a gap becomes significant, financially constrained companies should have a higher sensitivity of investment to fluctuations in operating cash flows. Financially constrained companies are interpreted as firms exhausting most of their internal funds, and thus rejecting profitable investments due to the existing discrepancy between internal and external sources of finance [34]. The bigger the wedge between the cost of internal and external funds, the more financially constrained the company is [30, p. 173].

As the topic of financial constraints and their impact on corporate investment grew in popularity, some researchers started to include conglomerates first, then group-affiliated companies into samples to test whether a company's access to an internal capital market matters in terms of investment. Hoshi, Kashyap and Scharfstein were among the first to analyse the impact of internal capital market on the financial constraints of companies affiliated with a business group [29]. Their study revealed that group-affiliated Japanese companies in the 1960s-1980s showed on average a lower sensitivity of investment to cash flow in comparison to stand-alone firms, thus demonstrating that internal capital markets helped mitigate the underinvestment problem caused by external capital market imperfections. Though focusing on multidivisional companies instead of business groups, H. Shin and R. Stulz showed that internal capital markets help implement profitable investment projects that otherwise would be foregone due to asymmetric information and agency costs. They also suggested to consider an internal capital market efficient if it allows to real- 
locate limited funds in a way that maximises shareholder wealth [41, p. 533], i.e. channels the financing resources to divisions with better investment opportunities.

Existing studies show that the functioning of internal capital market as a mechanism for easing financial constraints of business group-affiliated companies leads to several key consequences. First of all, provided that the use of internal capital markets is led by the financing advantage motive, investments in fixed assets of group affiliated companies turn out to be less sensitive to fluctuations in the firms' own cash flows, but respond to changes in the aggregate cash flows of other companies in the group [34;26]. Consequently, internal capital markets can alleviate the adverse effects of financial shocks, especially of financial crises [1]. Secondly, under limited external financing, due to the access to inside funds, those business groups that are organised as pyramids may enjoy financing advantages in relation not only to new investment projects, but also to the setting up of new firms [7]. Finally, the positive effects from the functioning of the internal capital markets are especially significant for more capital-intensive firms [6].

In Russia, according to S. B. Avdasheva, already in the first half of the 2000s internal capital markets of those Russian business groups that did not pay dividends on ordinary shares developed more actively [5, p. 40] in line with the financing advantage hypothesis. Currently the existence of cross-subsidisation practice in Russian business groups is noted by A. V. Zhiganov and A. Y. Yudanov [44].

According to V. A. Cherkasova, the degree of financing constraints of Russian companies is affected by their asset liquidity as well as by firm size, leverage, dividend payout ratio and asset tangibility [13].

\section{Research hypotheses}

Based on the analysis of existing studies we put forward a set of hypotheses to be tested within the empirical part of the research.

Hypothesis 1. Consistent with an active internal capital market assumption, investments of subsidiaries are positively affected by the cash flows of their group $[3 ; 23 ; 26]$ (H1p). Assuming that the use of internal capital markets is driven by the financing constraints mitigation motive, the subsidiary investments are less sensitive to the company's own cash flow (a proxy for the company's internal funds) than to the group cash flow (a proxy for the intragroup funds available through the internal capital market) measured as the cash flow of the parent company indicated in its consolidated statements (H1s).

The investment modelling of group-affiliated companies enables us to analyse indirectly the internal capital market efficiency by which we imply the reallocation of intragroup funds towards group members with higher investment opportunities. In this regard, we formulate our expectations as follows:

Hypothesis 2. In line with the financing advantage motive for the use of internal capital markets, there is a negative relationship between the investment opportunities of a parent company and the investments of subsidiaries [23; 25] $(H 2 p)$ and a positive relationship between the firm's own investment opportunities and its investments [24] (H2s).

We also test a range of hypotheses about control variables.

Hypothesis 3. There is a positive relationship between the investments of a subsidiary and the sales of the subsidiary itself $(H 3 s)$ as well as of its parent company $(H 3 p)$ in line with the accelerator effect [34].

Hypothesis 4. Investments of subsidiaries are positively affected by the size of the subsidiaries themselves ( $\mathrm{H} 4 \mathrm{~s}$ ) and their parent companies (H4p) as larger companies and business groups are expected to have a preferential access to external financing and thus be less financially constrained.

Hypothesis 5. Subsidiary investments in fixed assets are adversely affected by the share of long-term financial assets of the company (H5).

Hypothesis 6. There is a positive relationship between the investments of a subsidiary and the cash reserves of the subsidiary itself (H6s) as well as of its parent company (H6p), as higher liquidity should facilitate investment, all other things being equal.

Hypothesis 7. Investments of subsidiaries are adversely affected by the leverage of the subsidiaries themselves $(H 7 s)$ and their parent companies $(H 7 p)$ as higher indebtedness may lead to lower creditworthiness and decrease the future availability of funds to finance investments.

Hypothesis 8. Corporate investment in fixed assets positively depends on its level in the previous reporting period (H8).

\section{Methodology}

To assess the impact of the internal capital markets on financial constraints and investments of Russian group-affiliated companies we apply a classic framework based on the investment - cash flow sensitivity analysis, i.e. evaluate empirically the influence of operating cash flows (as well as traditional financial determinants) on the investments in fixed assets. Existing studies widely employ two types of investment models, namely the Q model of investment and the Euler equation model [24]. As estimation of the replacement cost of assets appears to be an ambiguous practical task creating a risk of Tobin's Q mismeasurement and obtaining biased results, we apply the Euler equation model in this study. It implies that a firm's current investments are determined by its past investments and various financial factors.

Thus, we estimate the following model:

$$
\begin{aligned}
& I_{i, t}=\beta_{0}+\beta_{1} \text { Sales }_{i, t}^{s}+\beta_{2} \text { Sales }_{i, t}^{h}+\beta_{3} \text { SIZE E }_{i, t-1}^{s}+ \\
& +\beta_{4} \text { SIZE }_{i, t-1}^{h}+\beta_{5} \text { Cash Flow }_{i, t}^{s}+\beta_{6} \text { Cash Flow }_{i, t}^{h}+ \\
& +\beta_{7} \text { ROA }_{i, t}^{s}+\beta_{8} \text { ROA }_{i, t}^{h}+\beta_{9} \text { Financial Assets }_{i, t-1}^{s}+ \\
& +\beta_{10} \text { Cash }_{i, t-1}^{s}+\beta_{11} \text { Cash }_{i, t-1}^{h}+\beta_{12} \text { Debt }_{i, t-1}^{s}+ \\
& +\beta_{13} \text { Debt }_{i, t-1}^{h}+\beta_{14} I_{i, t-1}+\varepsilon_{i, t}(1)
\end{aligned}
$$


In the equation (1) $i$ is the number of a firm; $t$ is a year and the superscripts $s$ and $h$ denote a company itself (a subsidiary) and its parent (holding) company, correspondingly; $I_{i, t}$ is the investments in fixed assets divided by beginning of year total assets; $T A_{i, t-1}$ denotes beginning of year total assets of a company; $S I Z E_{i, t-1}$ is measured as a natural logarithm of beginning of year

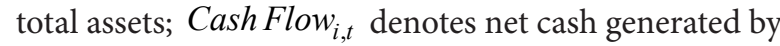
operating activities divided by beginning of year total assets; $R O A_{i, t}$ is return on total assets calculated as net profit divided by average annual total assets; $R O A_{i, t}$ net cash generated by operating activities divided by beginning of year total assets; Financial Assets $s_{i, t-1}^{s}$ denotes non-current financial assets scaled by total assets at the beginning of year $\mathrm{t}$; Sales $_{i, t}$ is measured as sales divided by beginning of year total assets; $C a s h_{i, t-1}$ and $D e b t_{i, t-1}$ are cash and cash equivalents and total liabilities scaled by total assets at the beginning of year $t$, correspondingly; $\varepsilon_{i, t}$ is an error term.

Following a widely-used approach, [e.g. in 26; 13; 3], we apply the ratio of annual investments in fixed assets to beginning of year total assets of a company to characterise corporate investment activity. We construct two different dependent variables by measuring investments in fixed assets: (1) as an annual increase in the carrying value of fixed assets (based on a statement of financial position Investment SFP) and (2) as an acquisition of non-current assets (based on a statement of cash flows - Investment $S C F)$.

We do not use ordinary least squares to estimate our models due to possible endogeneity problems and measurement errors that are typical for investment studies. All specifications of the investment model in equation (1) are estimated with the use of the generalised method of moments (GMM) with asymptotic standard errors for potential heteroskedasticity. We apply GMM difference (GMM-DIF) as well as GMM system (GMM-SYS) estimators, but, following L. Laeven, we use only two-step GMM estimates since: (1) they are more efficient than one-step estimates, and (2) only they allow Sargan test on over-identifying restrictions to be heteroskedasticity-consistent [35, p. 21].

\section{Empirical research}

By testing the above-mentioned hypotheses in our empirical analysis, we aim to address the following two questions: (1) Are Russian group-affiliated companies using internal capital market to reallocate financial resources? (2) If yes, are internal capital markets efficient? To find relevant answers we built empirical investment models using a set of 514 Russian group-affiliated companies and the period from 2014 to 2018.

As a first step to identify Russian business groups we formed a list of parent companies whose subsidiaries were subsequently checked for the possibility to be included in the research sample. Within this step we analysed all Russian companies with ordinary shares included in the
Moscow Exchange quotation list as of 01.10.2019. We then excluded the following from this initial set:

- Banks, insurance and real estate companies;

- Companies in which the state and/or municipalities either control at least $20 \%$ of shares or have a special right (a so-called 'golden share') to participate in corporate governance;

- Companies that did not publish their annual financial statements under IFRS at least once within the period of 2013-2018.

State-controlled business groups were left outside of our analysis for two reasons. First, it is bureaucrats who perform control over companies with predominant state participation and their goals are often determined by political interests rather than public welfare. Second, while control rights in state-controlled companies are highly concentrated, cash flow rights are widely dispersed among all taxpayers [42, p. 768].

The second step of the sample construction was aimed at identifying subsidiaries to be further included in the study. We analysed ownership chains of the parent companies selected at the first step with the use of 'Company Connections' tool offered by the SPARK database. We identified 800 firms registered no later than December 2013 and controlled (with ownership stakes no less than $50 \%$ of shares along the whole ownership chain) by selected public companies during 2013-2018.

Following other studies [e.g. 15; 24] we then excluded 169 companies with zero values of total assets and/or total revenue at the end of at least one year within 2013-2018 as they might have undergone restructuring or bankruptcy. We also excluded companies with zero book value of fixed assets at the beginning or end of at least one year within the period under investigation.

As a result, the final sample for our empirical study included 514 Russian companies affiliated with 48 nonstate business groups. The five-year study period chosen (2014-2018) and the sampling design allowed us to obtain a balanced panel data set of 2570 firm-year observations. Table 1 presents information on the industry structure of the sample:

Table 1. Industry structure of the sample

\begin{tabular}{|c|c|c|}
\hline $\begin{array}{l}\text { Industry (of a } \\
\text { parent company) }\end{array}$ & $\begin{array}{l}\text { Parent } \\
\text { companies }\end{array}$ & Subsidiaries \\
\hline Metals and mining & 12 & 232 \\
\hline $\begin{array}{l}\text { Consumer goods } \\
\text { and trade }\end{array}$ & 8 & 49 \\
\hline
\end{tabular}

$\begin{array}{ccc}\text { Power industry } & 7 & 12 \\ \text { Chemical industry } & 5 & 52\end{array}$

IT \& 4 11

Telecommunications 


\begin{tabular}{|c|c|c|}
\hline $\begin{array}{l}\text { Industry (of a } \\
\text { parent company) }\end{array}$ & $\begin{array}{l}\text { Parent } \\
\text { companies }\end{array}$ & Subsidiaries \\
\hline Oil \& Gas & 4 & 90 \\
\hline $\begin{array}{l}\text { Mechanical } \\
\text { engineering }\end{array}$ & 3 & 8 \\
\hline $\begin{array}{l}\text { Construction and } \\
\text { development }\end{array}$ & 3 & 25 \\
\hline Transport & 1 & 2 \\
\hline Finance & 1 & 33 \\
\hline Total & 48 & 514 \\
\hline
\end{tabular}

Source: Author's own calculations.

Table 2 presents descriptive statistics of the variables used. It shows that on average parent companies are more profitable than their subsidiaries $(7.2 \%$ versus $5.2 \%$, correspondingly), have a higher level of liquidity captured by both cash flows (13\% of total assets versus 5\%) and cash reserves (7.4\% versus $5.0 \%$ ) and are slightly more levered (with debt-to-assets ratios of $70.3 \%$ versus $66.2 \%$, correspondingly).

Subsequently, we also resorted to mitigation of the possible impact of extreme observations in the sample as an additional fourth step to improve the quality of the results as well as to check their robustness. There are two common approaches for reducing the effect of outliers that imply:

Table 2. Descriptive statistics of tested variables
1) using some rule of thumb to remove observations that are considered as outliers (in this case a sample is reduced based on the parameters set by a researcher, that are maximum/minimum regressor values allowed);

2) data winsorisation that refers to replacing extreme values by the maximum and/or minimum data at the threshold.

The first approach (data trimming) is often used in empirical modeling, including investment analysis. M. Deloof deleted firm-year observations with zero revenue values and/or with the value of revenue growth higher than $100 \%$ [16]. L. Laeven excluded observations with non-positive investments or fixed assets as well as observations with extreme values of the investment-to-capital ratio (those beyond the range of 0.1 -0.5 ), the sales-to-capital ratio (those beyond the range of $0.1-10$ ), the cash flow-to-capital ratio (those beyond the range of $0.01-1$ ) [35]. J. H. Mota and coauthors deleted companies with negative operating profit, EBIT [37]. Though this approach is widely used in research, we do not apply it in this study because it forms a specific, nonrandom sample, negatively affecting the results representativeness. Therefore, to eliminate outliers we apply the second approach and winsorise data at the $1 \%$ and $99 \%$ levels following another group of researchers $[21 ; 2 ; 3]$.

To address the issue of potential multicollinearity in the model we estimated a correlation matrix (Table 3). Absolute values of all pair correlation coefficients are less than 0.5 and show the absence of close relationships between explanatory variables. It enables us to assess the risks of multicollinearity as low.

\begin{tabular}{|c|c|c|c|c|c|}
\hline Variable & Mean & Median & Standard deviation & Minimum & Maximum \\
\hline Size (subsidiary) & 13.7 & 13.6 & 2.44 & 7.24 & 21.2 \\
\hline Size (parent) & 19.4 & 19.6 & 1.71 & 13.7 & 22.6 \\
\hline Cash Flow (subsidiary) & 0.05 & 0.03 & 0.335 & -6.10 & 2.62 \\
\hline Cash Flow (parent) & 0.130 & 0.133 & 0.107 & -0.331 & 2.28 \\
\hline ROA (subsidiary) & 0.052 & 0.038 & 0.237 & -3.24 & 1.50 \\
\hline ROA (parent) & 0.072 & 0.069 & 0.165 & -1.51 & 0.647 \\
\hline Financial assets (subsidiary) & 0.054 & 0.000 & 0.147 & 0.000 & 0.976 \\
\hline Cash (subsidiary) & 0.050 & 0.009 & 0.106 & 0.000 & 0.912 \\
\hline Cash (parent) & 0.074 & 0.053 & 0.070 & -0.003 & 0.357 \\
\hline Debt (subsidiary) & 0.662 & 0.574 & 0.709 & 0.000 & 9.05 \\
\hline Debt (parent) & 0.703 & 0.614 & 0.500 & 0.087 & 5.02 \\
\hline Sales (subsidiary) & 2.32 & 1.37 & 2.87 & 0.000 & 54.2 \\
\hline Sales (parent) & 0.881 & 0.803 & 0.613 & 0.002 & 9.27 \\
\hline
\end{tabular}

Source: Author's own calculations. 
Table 3. Correlation matrix for the variables used

\begin{tabular}{|c|c|c|c|c|c|c|c|c|}
\hline & 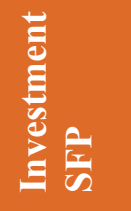 & 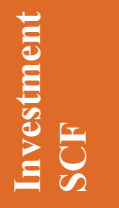 & 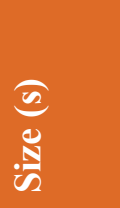 & $\begin{array}{c}3 \\
\frac{8}{\pi} \\
\frac{8}{0}\end{array}$ & 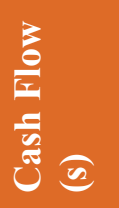 & $\frac{3}{\frac{3}{6}} \sqrt{\frac{1}{\sigma}}$ & 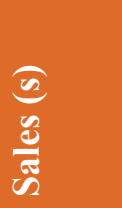 & 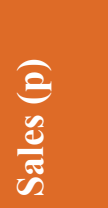 \\
\hline Investment SFP & 1.0 & 0.832 & -0.037 & -0.009 & -0.013 & 0.034 & -0.026 & 0.051 \\
\hline Investment SCF & & 1.0 & -0.018 & 0.012 & -0.006 & 0.051 & -0.030 & -0.000 \\
\hline Size (s) & & & 1.0 & 0.351 & 0.065 & 0.062 & -0.290 & -0.064 \\
\hline Size (p) & & & & 1.0 & 0.065 & 0.302 & -0.021 & -0.256 \\
\hline Cash Flow (s) & & & & & 1.0 & 0.028 & 0.033 & 0.027 \\
\hline Cash Flow (p) & & & & & & 1.0 & 0.008 & -0.129 \\
\hline Sales (s) & & & & & & & 1.0 & 0.151 \\
\hline \multirow[t]{2}{*}{ Sales (p) } & & & & & & & & 1.0 \\
\hline & 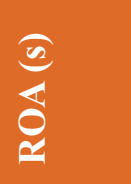 & $\underset{\Theta}{\stackrel{3}{6}}$ & 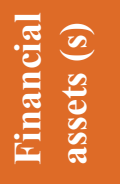 & $\underset{\frac{a}{0}}{\frac{\pi}{0}}$ & $\begin{array}{c}\hat{3} \\
\overline{\bar{c}} \\
\bar{v}\end{array}$ & $\begin{array}{l}\text { a } \\
\frac{\overrightarrow{0}}{0} \\
0\end{array}$ & $\begin{array}{l}\widehat{3} \\
\text { aे } \\
\text { อ }\end{array}$ & \\
\hline Investment SFP & -0.001 & 0.040 & -0.003 & 0.071 & -0.021 & -0.007 & -0.001 & \\
\hline Investment SCF & -0.004 & 0.021 & -0.021 & 0.049 & -0.012 & -0.006 & 0.006 & \\
\hline Size (s) & 0.101 & 0.025 & 0.234 & -0.254 & -0.140 & -0.181 & -0.060 & \\
\hline Size (p) & 0.109 & 0.209 & -0.025 & 0.000 & -0.074 & -0.183 & -0.313 & \\
\hline Cash Flow (s) & 0.363 & 0.048 & -0.008 & -0.023 & -0.028 & -0.097 & -0.050 & \\
\hline Cash Flow (p) & 0.050 & 0.304 & -0.036 & 0.029 & 0.233 & -0.119 & -0.133 & \\
\hline Sales (s) & 0.071 & 0.083 & -0.169 & 0.083 & 0.038 & 0.245 & -0.062 & \\
\hline Sales $(p)$ & 0.025 & -0.015 & -0.018 & -0.070 & 0.001 & 0.133 & 0.072 & \\
\hline ROA (s) & 1.0 & 0.119 & 0.009 & -0.079 & -0.034 & -0.170 & -0.080 & \\
\hline $\mathrm{ROA}(\mathrm{p})$ & & 1.0 & -0.074 & 0.052 & 0.240 & -0.127 & -0.344 & \\
\hline Financial assets (s) & & & 1.0 & -0.102 & -0.018 & -0.107 & 0.150 & \\
\hline Cash (s) & & & & 1.0 & 0.242 & -0.067 & -0.001 & \\
\hline Cash (p) & & & & & 1.0 & -0.044 & 0.015 & \\
\hline Debt (s) & & & & & & 1.0 & 0.210 & \\
\hline $\operatorname{Debt}(p)$ & & & & & & & 1.0 & \\
\hline
\end{tabular}

Comments: (s) stands for subsidiary, (p) stands for parent company.

Source: Author's own calculations.

We first use unwinsorised data to estimate several specifications of the investment model differing on the estimators (either GMM-DIF or GMM-SYS) and the dependent variable (either Investment SFP or Investment SFP) used. Table 4 reports the estimation results: 
Table 4. Investment model estimation results (unwinsorised data)

\begin{tabular}{|c|c|c|c|c|}
\hline & (1) & $(2)$ & (3) & (4) \\
\hline Dependent variable & Investment SFP & Investment SFP & Investment SCF & Investment SCF \\
\hline Estimator & GMM-DIF & GMM-SYS & GMM-DIF & GMM-SYS \\
\hline \multirow{2}{*}{ Lagged investment } & 0.0061 & $0.0143^{* * *}$ & -0.0004 & 0.0019 \\
\hline & $(0.0059)$ & $(0.0046)$ & $(0.0033)$ & $(0.0048)$ \\
\hline \multirow{2}{*}{ Size (subsidiary) } & $-0.1418^{\star * *}$ & 0.0007 & $-0.0297^{\star *}$ & $0.0022^{\star *}$ \\
\hline & $(0.0382)$ & $(0.0020)$ & $(0.0130)$ & $(0.0010)$ \\
\hline \multirow{2}{*}{ Size (parent) } & $0.1176^{* * *}$ & 0.0008 & $0.0403^{* *}$ & $0.0044^{* * *}$ \\
\hline & $(0.0336)$ & $(0.0020)$ & $(0.0163)$ & $(0.0014)$ \\
\hline \multirow{2}{*}{ Cash Flow (subsidiary) } & $-0.0008^{*}$ & 0.0002 & 0.0001 & 0.0002 \\
\hline & $(0.0005)$ & $(0.0003)$ & $(0.0004)$ & $(0.0003)$ \\
\hline \multirow{2}{*}{ Cash Flow (parent) } & 0.0439 & 0.0742 & -0.0261 & 0.0050 \\
\hline & $(0.0897)$ & $(0.0633)$ & $(0.0305)$ & $(0.0209)$ \\
\hline \multirow{2}{*}{ ROA (subsidiary) } & -0.0108 & -0.0158 & -0.0315 & -0.0153 \\
\hline & $(0.0435)$ & $(0.0275)$ & $(0.0242)$ & $(0.0129)$ \\
\hline \multirow{2}{*}{ ROA (parent) } & 0.0384 & 0.0315 & -0.0239 & -0.0081 \\
\hline & $(0.0374)$ & $(0.0291)$ & $(0.0184)$ & $(0.0114)$ \\
\hline \multirow{2}{*}{ Financial assets (subsidiary) } & 0.0112 & -0.0179 & 0.0999 & -0.0012 \\
\hline & $(0.0415)$ & $(0.0166)$ & $(0.0822)$ & $(0.0271)$ \\
\hline \multirow{2}{*}{ Cash (subsidiary) } & 0.0127 & 0.0072 & 0.0056 & -0.0190 \\
\hline & $(0.0538)$ & $(0.0194)$ & $(0.0216)$ & $(0.0142)$ \\
\hline \multirow{2}{*}{ Cash (parent) } & -0.2056 & $-0.1019^{\star}$ & 0.0499 & $0.0754^{* *}$ \\
\hline & $(0.1336)$ & $(0.0566)$ & $(0.0798)$ & $(0.0340)$ \\
\hline \multirow{2}{*}{ Debt (subsidiary) } & -0.0483 & $-0.0128^{\star *}$ & -0.0032 & -0.0066 \\
\hline & $(0.0324)$ & $(0.0055)$ & $(0.0082)$ & $(0.0043)$ \\
\hline \multirow{2}{*}{ Debt (parent) } & -0.0108 & -0.0013 & 0.0316 & 0.0003 \\
\hline & $(0.0320)$ & $(0.0055)$ & $(0.0215)$ & $(0.0039)$ \\
\hline \multirow{2}{*}{ Sales (subsidiary) } & $-0.0059^{\star}$ & 0.0013 & 0.0066 & 0.0024 \\
\hline & $(0.0033)$ & $(0.0009)$ & $(0.0051)$ & $(0.0015)$ \\
\hline \multirow{2}{*}{ Sales (parent) } & $0.0708^{\star *}$ & $0.0253^{* * *}$ & 0.0077 & 0.0022 \\
\hline & $(0.0286)$ & $(0.0075)$ & $(0.0107)$ & $(0.0034)$ \\
\hline \multirow{2}{*}{ Constant } & 0.0003 & -0.0395 & 0.0026 & $-0.0872^{\star * \star}$ \\
\hline & $(0.0101)$ & $(0.0448)$ & $(0.0065)$ & $(0.0272)$ \\
\hline Year dummies & YES & YES & YES & YES \\
\hline Observations & 1542 & 2056 & 1542 & 2056 \\
\hline$A R(1): p$-value & 0.1677 & 0.1585 & 0.0957 & 0.0979 \\
\hline $\operatorname{AR}(2): p$-value & 0.1357 & 0.4434 & 0.4255 & 0.4735 \\
\hline Sargan test: p-value & 0.6943 & 0.8946 & 0.2507 & 0.1159 \\
\hline $\begin{array}{l}\text { Wald test of joint significance: } \\
\text { p-value }\end{array}$ & 0.0288 & 0.0013 & 0.5170 & 0.0000 \\
\hline $\begin{array}{l}\text { Wald test (year dummies): } \\
\text { p-value }\end{array}$ & 0.9426 & 0.3310 & 0.5752 & 0.3824 \\
\hline
\end{tabular}

Comments: ${ }^{*}$ - significance at the $10 \%$ level; ${ }^{* *}$ - significance at the $5 \%$ level; ${ }^{* *}$ - significance at the $1 \%$ level. Standard errors in parentheses.

Source: Author's own calculations. 
We consider the consistency of estimations by presenting a Sargan test on over-identifying restrictions. As all the p-values reported are 0.11 and above, the null hypothesis implying the validity of instruments is not rejected even at the $10 \%$ significance level. The reliability of results also depends on the assumption that the error terms do not exhibit autocorrelation. Both the first-order and second-order serial correlation tests indicate inexistence of the autocorrelation problems. We also report Wald tests for joint significance of all the parameters. As the null hypotheses refer to insignificance, low p-values (for models 1, 2 and 4) imply joint significance for all independent variables.

Estimation results provide evidence that companies affiliated with larger business groups invest more in fixed assets, ceteris paribus (in line with $H 4 p$ ). At the same time, it is impossible to draw unambiguous conclusions on the influence of a company's size on its investment activity (H4s) as two models out of four reported a negative effect, while the rest two models imply a positive impact and no significant effect, respectively. There is some empirical evidence that business group lagged sales have a positive impact on the investments in fixed assets of affiliated companies (in support of H3p). Contradictory evidence is obtained on the relationship between the level of cash holdings in a business group and investments made by its affiliated companies (H6p).

The first model estimation results imply that a company's investment activity is adversely affected by its leverage measured as total debt-to-assets ratio (H7s) as well as by company's own operating cash flows. Considering the insignificance of company's operating cash flows in other estimated models, this evidence implies that Russian group-affiliated companies did not experience significant financial constraints during 2014-2018.

To further investigate the investment patterns of Russian companies we continue our modelling by winsorising all explanatory variables (except for both company and group size) at the top and bottom $1 \%$ of their distribution. Using the data without outliers we re-estimate the models (1)-(4), the results are provided in the Table 5:

Table 5. Investment model estimation results (winsorised data)

\begin{tabular}{|c|c|c|c|c|}
\hline & (1) & $(2)$ & (3) & (4) \\
\hline Dependent variable & Investment SFP & Investment SFP & Investment SCF & Investment SCF \\
\hline Estimator & GMM-DIF & GMM-SYS & GMM-DIF & GMM-SYS \\
\hline Lagged investment & $\begin{array}{l}0.1074 * * \\
(0.0472)\end{array}$ & $\begin{array}{l}0.1424 * * * \\
(0.0418)\end{array}$ & $\begin{array}{l}0.2306 * * * \\
(0.0805)\end{array}$ & $\begin{array}{l}0.2283 * * * \\
(0.0562)\end{array}$ \\
\hline Size (subsidiary) & $\begin{array}{l}-0.0672 * * * \\
(0.0138)\end{array}$ & $\begin{array}{l}0.0014 \\
(0.0012)\end{array}$ & $\begin{array}{l}-0.0224 * * * \\
(0.0065)\end{array}$ & $\begin{array}{l}0.0025 * * * \\
(0.0008)\end{array}$ \\
\hline Size (parent) & $\begin{array}{l}0.0743 * * * \\
(0.0206)\end{array}$ & $\begin{array}{l}-0.0002 \\
(0.0016)\end{array}$ & $\begin{array}{l}0.0329 * * \\
(0.0137)\end{array}$ & $\begin{array}{l}0.0020 * \\
(0.0011)\end{array}$ \\
\hline Cash Flow (subsidiary) & $\begin{array}{l}-0.0104 \\
(0.0146)\end{array}$ & $\begin{array}{l}-0.0050 \\
(0.0127)\end{array}$ & $\begin{array}{l}0.0226 * \\
(0.0120)\end{array}$ & $\begin{array}{l}0.0200 * * \\
(0.0094)\end{array}$ \\
\hline Cash Flow (parent) & $\begin{array}{l}0.0016 \\
(0.0503)\end{array}$ & $\begin{array}{l}0.0016 \\
(0.0334)\end{array}$ & $\begin{array}{l}-0.0236 \\
(0.0335)\end{array}$ & $\begin{array}{l}0.0107 \\
(0.0232)\end{array}$ \\
\hline ROA (subsidiary) & $\begin{array}{l}-0.0033 \\
(0.0272)\end{array}$ & $\begin{array}{l}-0.0038 \\
(0.0179)\end{array}$ & $\begin{array}{l}-0.0329 * * \\
(0.0146)\end{array}$ & $\begin{array}{l}-0.0214 * * \\
(0.0101)\end{array}$ \\
\hline ROA (parent) & $\begin{array}{l}0.0466 * \\
(0.0264)\end{array}$ & $\begin{array}{l}0.0511 * * \\
(0.0226)\end{array}$ & $\begin{array}{l}0.0001 \\
(0.0168)\end{array}$ & $\begin{array}{l}0.0029 \\
(0.0141)\end{array}$ \\
\hline Financial assets (subsidiary) & $\begin{array}{l}0.0098 \\
(0.0290)\end{array}$ & $\begin{array}{l}-0.0070 \\
(0.0126)\end{array}$ & $\begin{array}{l}0.0077 \\
(0.0176)\end{array}$ & $\begin{array}{l}-0.0285 * * * \\
(0.0086)\end{array}$ \\
\hline Cash (subsidiary) & $\begin{array}{l}0.0110 \\
(0.0388)\end{array}$ & $\begin{array}{l}0.0091 \\
(0.0214)\end{array}$ & $\begin{array}{l}0.0248 \\
(0.0247)\end{array}$ & $\begin{array}{l}-0.0024 \\
(0.0144)\end{array}$ \\
\hline Cash (parent) & $\begin{array}{l}-0.0914 \\
(0.0826)\end{array}$ & $\begin{array}{l}-0.0552 \\
(0.0377)\end{array}$ & $\begin{array}{l}-0.0131 \\
(0.0506)\end{array}$ & $\begin{array}{l}0.0378 \\
(0.0240)\end{array}$ \\
\hline Debt (subsidiary) & $\begin{array}{l}-0.0086 \\
(0.0153)\end{array}$ & $\begin{array}{l}-0.0089 * \\
(0.0047)\end{array}$ & $\begin{array}{l}-0.0131 * \\
(0.0075)\end{array}$ & $\begin{array}{l}-0.0094 * * * \\
(0.0033)\end{array}$ \\
\hline
\end{tabular}




\begin{tabular}{|c|c|c|c|c|}
\hline & (1) & (2) & (3) & (4) \\
\hline Debt (parent) & $\begin{array}{l}0.0169 \\
(0.0249)\end{array}$ & $\begin{array}{l}0.0015 \\
(0.0061)\end{array}$ & $\begin{array}{l}0.0299 * \\
(0.0161)\end{array}$ & $\begin{array}{l}-0.0002 \\
(0.0043)\end{array}$ \\
\hline Sales (subsidiary) & $\begin{array}{l}-0.0017 \\
(0.0026)\end{array}$ & $\begin{array}{l}0.0027 * * * \\
(0.0009)\end{array}$ & $\begin{array}{l}0.0034 * \\
(0.0021)\end{array}$ & $\begin{array}{l}0.0012 * \\
(0.0006)\end{array}$ \\
\hline Sales (parent) & $\begin{array}{l}0.0125 \\
(0.0125)\end{array}$ & $\begin{array}{l}-0.0021 \\
(0.0034)\end{array}$ & $\begin{array}{l}0.0041 \\
(0.0096)\end{array}$ & $\begin{array}{l}-0.0013 \\
(0.0030)\end{array}$ \\
\hline Constant & $\begin{array}{l}-0.0047 \\
(0.0059)\end{array}$ & $\begin{array}{l}-0.0057 \\
(0.0350)\end{array}$ & $\begin{array}{l}0.0008 \\
(0.0034)\end{array}$ & $\begin{array}{l}-0.0473 * * \\
(0.0205)\end{array}$ \\
\hline Year dummies & YES & YES & YES & YES \\
\hline AR(1): p-value & 0.0000 & 0.0000 & 0.0000 & 0.0000 \\
\hline AR(2): p-value & 0.4071 & 0.7615 & 0.6697 & 0.5473 \\
\hline Sargan test: $\mathrm{p}$-value & 0.9760 & 0.9791 & 0.6032 & 0.4619 \\
\hline $\begin{array}{l}\text { Wald test of joint significance: } \\
\text { p-value }\end{array}$ & 0.0000 & 0.0000 & 0.0011 & 0.0000 \\
\hline Wald test (year dummies): p-value & 0.5503 & 0.1198 & 0.8789 & 0.5617 \\
\hline
\end{tabular}

Comments: * - significance at the $10 \%$ level; ** - significance at the $5 \%$ level; *** - significance at the $1 \%$ level. Standard errors in parentheses.

Source: Author's own calculations.

Even after reducing the effects of outliers the obtained results confirm the $H 8$ hypothesis implying that corporate investment in fixed assets positively depends on its level in the previous reporting period. Again, there is strong evidence that, all other things being equal, companies affiliated with larger business groups invest more (in line with $H 4 p$ ). Still the results do not allow us to make inambiguous conclusions on the effect of company's size on the investment activity ( $H 4 s$ is not confirmed). While group sales as a corporate investment factor appeared to lose its significance in the models based on winsorised data, the effect of companies' own sales on investment turned to be significantly positive in most models (in support of $\mathrm{H3s}$ ). In contrast to the models (1) - (4) that provided controversial evidence on the relationship between group cash reserves and the investments of group members, estimation results for models (5)-(8) based on winsorised data do not support existence of any significant effects of cash reserves (H6s and H6p not confirmed).

In support of the financing constraints mitigation motive, our modeling results show that investment activity of individual firms is subject to a negative impact of company leverage (in line with $H 7 s$ ) and a positive influence of group leverage (contrary to $H 7 p$ ). The more debt a company raises to finance its operations, the higher is the cost of using external funds and the degree of financial constraints. At the same time, a higher debt ratio of a whole business group may not cause a significant increase in the cost of borrowing of affiliated companies, due to the co-insurance effect $[11 ; 12]$, and debt capital attracted by a business group can be further distributed to group partici- pants with larger investment opportunities with the use of internal capital market.

Models (7) and (8) also reveal a positive impact of a company's operating cash flow on its investment activity that can be explained by limiting investment to available internal funds due to higher costs of external financing, i.e. by the presence of financial constraints [37, p.11]. Considering that there is no significant influence of cash flows of parent companies on the investments of subsidiaries, we can state that hypotheses H1P and H1s (being consistent with the financing constraints mitigation motive) are declined, and internal capital markets of Russian business groups, though active, still fail to eliminate financial constraints of affiliated companies.

Finally, the second group of models in total demonstrates that profitability (considered as a proxy of investment opportunities) of a business group has a positive impact on the investments of participating companies, while profitability of a company itself is negatively related to the level of investment in fixed assets (contrary to H2p and $H 2 s$, correspondingly). It can be interpreted as an evidence for cross-subsidisation taking place in Russian business groups and is more consistent with the propping motive for the internal capital market usage [41, p. 533]. This finding contradicts the internal capital market efficiency assumption implying that intragroup financing operations should stimulate investment activity of more profitable group members. As such, this does not match the financing advantage motive behind the use of internal capital markets. 


\section{Conclusion}

Nowadays, mechanisms for easing financing constraints are of special importance for Russian companies, due to the limited availability of internal and external sources of funds (caused by an unstable macroeconomic situation in Russia and sanctions imposed against a significant range of firms). In this regard, internal capital markets have a good potential to mitigate financial constraints of group-affiliated companies and to help boost the investments of the most profitable business units within business groups. In this study, we aimed at checking whether the use of internal capital markets in Russia is indeed motivated by this so-called financing advantage strategy of controlling shareholders, and not by tunneling or propping practices. To do so we have examined the determinants of investment activity of Russian group-affiliated companies to assess whether they are consistent with the financing constraints mitigation motive.

Summing up the empirical findings based on a wide range of Russian subsidiaries over the period from 2014 to 2018 , we state that the investment activity of Russian group-affiliated companies is dependent on both company and group characteristics. In support of the financing advantage motive behind the use of internal capital markets, subsidiary investments in fixed assets are adversely affected by a company leverage as a higher debt burden increases the degree of financial constraints by enlarging the gap between the costs of internal and external funds. Investments of subsidiaries are also positively influenced by their own sales in line with the accelerator effect. There is also evidence that investments in fixed assets demonstrate a positive dependency on their own lagged values and are negatively related to the share of long-term financial assets serving as an alternative investment option.

At the same time, subsidiaries' investments are also influenced by group characteristics, namely leverage and investment opportunities, proxied by ROA. In general, the significance of group factors shows that internal capital markets of Russian business groups are functioning, and actively enabling affiliated companies to use intragroup funds to finance investments. We find that members of more leveraged business groups invest more, ceteris paribus. This can be explained by the co-insurance effect, and thus should be interpreted in favor of the financing constraints mitigation motive.

Nevertheless, the efficiency of internal capital markets is not proven, as subsidiaries' investments are negatively affected by the companies' own asset profitability. This finding is more consistent with the propping motive for the internal capital market usage. Meanwhile, some evidence of a positive impact of company's operating cash flow on its investments in addition to the insignificance of cash flows of parent companies for the investments of subsidiaries demonstrate that the internal capital markets of Russian business groups, though active, still fail to eliminate the financial constraints of affiliated companies, and thus do not fully contribute to facilitation of investments.
Summing up, we conclude that currently the use of internal capital markets of Russian non-state business groups is driven partly by the financing constraints mitigation motive, partly by the propping motive, and should exert ambiguous effects on the intra-group funds allocation efficiency.

\section{References}

1. Almeida H., Campello M. Financial Constraints, Asset Tangibility, and Corporate Investment. The Review of Financial Studies. 2007;20(5):1429-1460. DOI: $10.1093 / \mathrm{rfs} / \mathrm{hhm} 019$

2. Almeida H., Kim C.-S., Kim H.B. Internal Capital Markets in Business Groups: Evidence from the Asian Financial Crisis. The Journal of Finance. 2015;70(6):2539-2586. DOI: 10.1111/jofi.12309

3. Ang A., Masulis R., Pham P.K., Zein J. Internal Capital Markets in Family Business Groups During the Global Financial Crisis. UNSW Business School Research Paper Forthcoming. 2018. 55 p. DOI: $10.2139 /$ ssrn. 2517810

4. Avdasheva S., Golikova V., Dolgopyatova T., Yakovlev A. Large new companies ('business groups') in the Russian transition economy: State of the problem in the economic literature. WP1/2005/09. Moscow: Higher School of Economics Publ.; 2005. 52 p. (in Russian)

5. Avdasheva S. Russian Holding Groups: New Empirical Evidence. Problems of Economic Transition. 2007;50(5):24-43. DOI: 10.2753/PET10611991500502

6. Belenzon S., Berkovitz T., Rios L.A. Capital Markets and Firm Organization: How Financial Development Shapes European Corporate Groups. Management Science. 2013;59(6):1326-1343. DOI: 10.1287/ mnsc. 1120.1655

7. Bena J., Ortiz-Molina H. Pyramidal ownership and the creation of new firms. Journal of Financial Economics. 2013;108:798-821. DOI: 10.1016/j. jineco.2013.01.009

8. Beyer B., Downes J., Rapley E.T. Internal capital market inefficiencies, shareholder payout, and abnormal leverage. Journal of Corporate Finance. 2017;43:39-57. DOI: 10.1016/j.jcorpfin.2016.12.009

9. Brodskiy, D. Investment strategy of a holding company. Candidate of Economic Sciences dissertation autoabstract. Moscow: Lomonosov Moscow State University; 2010. 29 p.

10. Buchuk D., Larrain B., Muñoz F., Urzúa F.I. The internal capital markets of business groups: Evidence from intra-group loans. Journal of Financial Economics. 2014;112:190-212. DOI: 10.1016/j. jfineco.2014.01.003 
11. Byun H., Choi S., Hwang L., Kim R.G. Business group affiliation, ownership structure, and the cost of debt. Journal of Corporate Finance. 2013;23:311-331. DOI: 10.1016/j.jcorpfin.2013.09.003

12. Chandera Y., Utama C.A., Husodo Z.A., Setia-Atmaja L. The co-insurance effect hypothesis and the cost of bank loans: Evidence from Indonesian pyramidal business groups. Global Finance Journal. 2018;37:100122. DOI: $10.1016 /$ j.gf.2018.03.003

13. Cherkasova V. The influence of financial constraint factors on investment activity of companies in developed and emerging capital markets. Economic Analysis: Theory and Practice. 2014;13(34):17-27 (in Russian).

14. Cherkasova V., Teplova O. Research on the influence of financial constraints on investment decisions of companies in emerging capital markets // Journal of Corporate Finance Research. 2013;7(2):4-21 (in Russian). DOI: 10.17323/j.jcfr.2073-0438.7.2.2013

15. Cleary S. The Relationship between Firm Investment and Financial Status. The Journal of Finance. 1999;54(2):673-692. DOI: 10.1111/0022-1082.00121

16. Deloof M. Internal capital markets, bank borrowing, and financing constraints: evidence from Belgian firms. Journal of Business Finance \& Accounting. 1998;25(7\&8):945-968. DOI: 10.1111/14685957.00220

17. Dementiev V. Russian financial and industrial groups: network-type integration experience. Management and business administration. 2007;1:116-130 (in Russian).

18. Dewaelheyns N., Van Hulle C. Internal Capital Markets and Capital Structure: Bank Versus Internal Debt. European Financial Management. 2010:16(3):345-373. DOI: 10.1111/j.1468036X.2008.00457.x

19. Djankov, S., La Porta, R., Lopez-de-Silanes, F., Shleifer, A. The law and economics of self-dealing. Journal of Financial Economics. 2008;88:430-465. DOI: 10.1016/j.jfineco.2007.02.007

20. Fazzari S.M., Hubbard R.G., Petersen B.C., Blinder A.S., Poterba J.M. Financing Constraints and Corporate Investment. Brookings Papers on Economic Activity. 1988;1988:141-206. DOI: 10.2307/2534426

21. Ferrando A., Marchica M.-T., Mura R. Financial Flexibility and Investment Ability Across the Euro Area and the UK. European Financial Management. 2017;23(1):87-126. DOI: 10.1111/eufm.12091.

22. Friedman E., Johnson S., Mitton J. Propping and tunneling. Journal of Comparative Economics. 2003;31:732-750. DOI: 10.1016/j.jce.2003.08.004

23. Gautier A., Hamadi M. Internal Capital Market Efficiency of Belgian Holding Companies. Presses universitaires de Grenoble. 2005;26(2):11-34.
24. George R., Kabir R., Qian J. Investment-cash flow sensitivity and financing constraints: New evidence from Indian business group firms. Journal of Multinational Financial Management. 2011;21:69-88. DOI: $10.1016 /$ j.mulfin.2010.12.003

25. Gopalan R., Nanda V., Seru A. Affiliated firms and financial support: Evidence from Indian business groups. Journal of Financial Economics. 2007;86:759795. DOI: 10.1016/j.jfineco.2006.09.008

26. Gugler K., Peev E., Segalla E. The internal workings of internal capital markets: Cross-country evidence. Journal of Corporate Finance. 2013;20:59-73. DOI: 10.1016/j.jcorpfin.2012.12.001

27. Jiang G., Lee C.M.C., Yue H. Tunneling through intercorporate loans: The China experience. Journal of Financial Economics. 2010;98:1-20. DOI: 10.1016/j. jineco.2010.05.002

28. Johnson, S., La Porta R., Lopez-de-Silanes F., Shleifer A. Tunneling. American Economic Review Papers and Proceedings. 2000;90:22-27. DOI: 10.1257/aer.90.2.22

29. Hoshi T., Kashyap A., Scharfstein D. Corporate Structure, Liquidity, and Investment: Evidence from Japanese Industrial Groups. The Quarterly Journal of Economics. 1991;106(1):33-60. DOI: 10.2307/2937905

30. Kaplan S.N., Zingales L. Do Investment-Cash Flow Sensitivities Provide Useful Measures of Financing Constraints? The Quarterly Journal of Economics. 1997;112(1):169-215. DOI: $10.1162 / 003355397555163$

31. Khanna T., Palepu K. The Future of Business Groups in Emerging Markets: Long-Run Evidence from Chile. The Academy of Management Journal. 2000;43(3):268-285. DOI: 10.2307/1556395

32. Korotkova Y.I. Internal capital market efficiency of business groups. Problems of Management Theory and Practice. 2019;7:100-115 (in Russian).

33. Kulemin A.N. Approaches to strategic financial management in a holding company. The Bulletin of Moscow University. Series 6. Economics. 2007;6:25-39 (in Russian).

34. Kumar S., Ranjani K.S. Financial constraints and investment decisions of listed Indian manufacturing firms. Financial Innovation. 2018;4(6):1-17. DOI: 10.1186/s40854-018-0090-4

35. Laeven L. Does Financial Liberalization Reduce Financing Constraints? Financial Management. 2003;32(1):5-34. DOI: 10.2307/3666202

36. Lensink R., van der Molen R., Gangopadhyay $\mathrm{S}$. Business groups, financing constraints and investment: the case of India. The Journal of Development Studies. 2003;40(2):93-119. DOI: $10.1080 / 00220380412331293787$ 
37. Mota J.H., dos Santos M.C. Does Internal Capital Market Membership Matter for Capital Allocation? Theory and Evidence from the Euro Area. CICEE Working Paper No.003/2019. 2019. 53 p. DOI: $10.2139 /$ ssrn. 3530191

38. Peng W.Q., Wei K.C.J., Yang Z. Tunneling or propping: Evidence from connected transactions in China. Journal of Corporate Finance. 2011;17:306325. DOI: 10.1016/j.jcorpfin.2010.08.002

39. Perotti E.C., Gelfer S. Red barons or robber barons? Governance and Investment in Russian Financial-Industrial Groups. European Economic Review. 2001;45:1601-1617. DOI: 10.1016/S00142921(00)00097-0

40. Russian Economy in 2018. Trends and Outlooks. Moscow: Gaidar Institute Publ.; 2019. 616 p.

41. Shin H.-H., Stulz R.M. Are Internal Capital Markets Efficient? The Quarterly Journal of Economics. 1998;113(2):531-552. DOI: $10.1162 / 003355398555676$

42. Shleifer, A., Vishny, R. A survey of corporate governance. Journal of Finance. 1997;52:737-783. DOI: 10.1111/j.1540-6261.1997.tb04820.x

43. Shumilov A., Volchkova N. Russian business groups: substitutes for missing institutions? Working Papers w0050. Moscow: New Economic School (NES); 2004. $16 \mathrm{p}$.

44. Zhiganov A.V., Yudanov A.Y. High-Growth Companies in Russia: The Influence of Affiliation on Growth Factors. Russian Management Journal. 2019:17(3):287-308 (in Russian). DOI: 10.21638/ spbu18.2019.301 